\title{
Characteristics Of Clay Tile With Rice Husk Ash On Absorption And Flexural Strength
}

\author{
Kukuh Kurniawan D. Sungkono ${ }^{1}$ \\ \{kukuhkds@utp.ac.id $\left.{ }^{1}\right\}$ \\ Tunas Pembangunan University, Surakarta, Indonesia ${ }^{1}$
}

\begin{abstract}
Rice husk ash (RHA) is very rich in the content of silica $\left(\mathrm{SiO}_{2}\right)$ or known as silica dioxide. The content of silica $\left(\mathrm{SiO}_{2}\right)$ in RHA reaches about $90 \%$. This study was to investigate the characteristics of clay tile which was added RHA originating from burning brick. Addition of RHA on clay tile is $0 \%, 2.5 \%, 5 \%$ and $7.5 \%$ by weight of clay. The results of seepage test, all of clay tile obtained no leakage or water droplets at the location in the water soak. The addition of $7.5 \%$ RHA resulted in an absorption of up to $18 \%$, and addition of $5 \%$ and $2.5 \%$ RHA is $14.8 \%$ and $14.8 \%$ in absorption test. Maximum flexural load was obtained by increasing the RHA by $7.5 \%$ which is average of $68.75 \mathrm{~kg}$, for the addition of $5 \%$ RHA and $2.5 \%$ is $65 \mathrm{~kg}$ and $66.25 \mathrm{~kg}$. And clay tile without RHA produces $60 \mathrm{~kg}$ bending load.
\end{abstract}

Keywords: rice husk ash, silica, clay tile.

\section{Introduction}

In Indonesia, clay tile is widely used as the roof of the house. Clay roof tile factory is much in production in rural areas that are around the agricultural area. In addition there is also a clay brick factory, which uses rice husks for the combustion process. In the manufacture of bricks during the combustion process with rice husk, will be produced rice husk ash (RHA). Brick burning temperature on surface is about $300^{\circ} \mathrm{C}$.

RHA is very rich in the content of silica $\left(\mathrm{SiO}_{2}\right)$ or known as silica dioxide. The content of silica $\left(\mathrm{SiO}_{2}\right)$ in RHA reaches about $90 \%$. In the construction world the use of silica compounds as an added material has been widely used especially on concrete to increase compressive strength. The added material in the concrete used today is the silica fume produced by the factory, so the price is very expensive. Another case with RHA which has a silica content which is the waste material from burning rice husks much cheaper.

Amorphous silica produced from RHA is thought to be an important source for producing pure silicon, silicon carbide, and silicon nitrid powder [1]

The rice husk is the outermost part of the rice grain which is a by-product when the rice milling process is done. About 20-35 percent of the weight of rice is rice husk and approximately fifteen percent of the rice husk composition is husk ash.

Silica dioxide (amorphous) from rice husks through several stages of the process, ie washing, drying, spraying, bleaching, and acidification. The highest content of $\mathrm{SiO}_{2}$ obtained by drying with sunlight for 1 hour that is equal to $88,97 \%$, compared with drying in oven $\left(190^{\circ} \mathrm{C}\right) 1$ hour which equal to $83,15 \%$. The percentage of weight loss from rice husk after combustion process is between $78.78-80.2 \%$. The most common value of the silica content of ICCSET 2018, October 25-26, Kudus, Indonesia

Copyright (C) 2018 EAI

DOI 10.4108/eai.24-10-2018.2280589 
husk ash is $90-96 \%$. The silica contained in the chaff has a hydrated amorphous structure. When combustion is carried out at temperatures above $650{ }^{\circ} \mathrm{C}$, crystallinity of $\mathrm{SiO}_{2}$ will increase so that the phase of kristobalit and tridimit can be formed. The higher the temperature in the process of stirring the husk in the oven will get higher $\mathrm{SiO}_{2}$ purity. Optimum temperature is $1000{ }^{\circ} \mathrm{C}$ with maximum silica content of $98.01 \%$ [2].

The change of rice husk to silica ash after undergoing carbonization process is also a potent source of pozzolan as SCM (Supplementary Cementitious Material). RHA has a very high pozzolanic content that is superior to other SCM like fly ash, slag, and silica fume. The silica content in RHA can be utilized in the construction world as an added material to increase the compressive strength. The added material in the concrete used today is the silica fume produced by the factory, so the price is very expensive. Another case with RHA which has a silica content which is the waste material from burning rice husks much cheaper.

Pozzolan is a material containing silica and Alumina compounds in which the pozzolan material itself does not have any cement-like properties, but with its fine shape and in the presence of water, the compounds will react chemically with Calcium hydroxide (the reaction compound between cement and water) at room temperature to form compounds Calcium Aluminate hydrate which has properties such as cement.

Clay roof tile with good quality must be made of good clay material that is elastic, not easy to crack and become red after burned. While the burning process carried out for approximately 12 hours, this is done to remove the water content in the roof. So that the rooftile becomes dry, solid and not easily broken.

With the addition of RHA, there was a change of compressive strength and porosity compared to tile without RHA mixture, optimum value for press testing and porosity test was obtained on tile with mixture of 5\% RHA composition with mean value of compressive strength $11.118 \mathrm{KPa}$ and porosity average value is $20.16 \%$. The main constituents of roof tile are clay and sand [3].

From the studies, it is observed that optimum proportionfor (RHA+Clay) bricks was observed as 30\% RHA and 70\% Clay (Maximum of 30\% RHA) as the bricks exhibited high compressive strength and low brick weight [4]

Partial replacement of clay with rice straw ash has a positive effect on physical and mechanical characteristics of bricks. Only on porosity testing did not meet SII-0021-1978 standard, the shrinkage test, specific gravity and compressive strength of brick meet SII-00211978 standard [5].

From the test results of the compressive strength of the brick before combustion and post combustion obtained the highest value of compressive strength is found in the sample of brick with a mixture of 5\% Abu Sekam Padi. Due to the influence of higher chemical content of $\mathrm{SiO}_{2}$ (Silica) contained in RHA. Thus, the test specimens with a mixture of RHA have greater compressive strength than the test specimens of the ashes of bagasse and the ash mixture (Fly Ash) [6].

There is a trend of reducing the inside temperature when the RHA percentage in the roof tile increases. This reduction of thermal conductivity may be due to the improved porous nature of the roof tile with the addition of RHA.[7]

The object of this study was to investigate the characteristics of clay tile which was added RHA rice originating from burning brick, water seepage test, absorption and flexural load test. 


\section{Material and Specimens}

\subsection{Material}

The clay used in this study was taken from the usual source for tile production in Balong, Blora, Central Java. RHA is used from the brick industry around Balong.

\subsection{Specimens of Clay Roof Tile}

In this study, the composite material consists of clay, water and RHA. The mixture of clay tile consists of the addition of RHA $0 \%, 2.5 \%, 5 \%$ and $7.5 \%$. The addition of RHA is based on the weight of clay.

Addition of water to clay mixture and RHA as necessary to make elatis. Because of the nature of RHA which absorbs the water content in the clay, and makes the mixture unelastic or breakable. The tile-making process in this study was done at the Balong tile factory, Blora, Central Java, from the process of mixing materials, molding, sun drying and burning in the furnace.

\section{Methodology}

\subsection{Water Seepage Test}

In this test is done with the steps that is, the surface of the tile fitted with a vessel to hold water, with tile on dry conditions (approximately $37 \mathrm{C}$ ) for 24 hours. Then the water vessel on the surface of the clay tile filled with water as high as $5 \mathrm{~cm}$ for 2 hours. Observe the bottom of the tile whether there is water droplets due to water seepage. In case of droplets caused by water seepage, clay tile is declared not to meet the standard of permabilitas (Regulation Ceramic Tile Indonesia, N.I-19. 1978. third printing [8]).

\subsection{Absorption Test}

The size of water absorption by mortar is affected by pores or cavities. The more pores the greater the absorption so that the resistance will decrease. The cavity (pore) occurs due to improper quality and composition of the material of its preparation. Influence of the ratio is too large can cause the cavity, because there is water that does not react and then evaporate and cause cavities.

The absorption test is carried out by first drying the clay roof in the oven at $100^{\circ} \mathrm{C}$ for 2 hours. After that clay tile in weigh (K), then soaked with water 24 hours. The tile that has been soaked weighed (W), then calculated by the following equations(1) to determine absorption.

$$
a=\frac{W-K}{K} 100 \%
$$

According to SNI 03-2095-1998 [9], maximum absorption of tile as in Table 1. 
Table 1. Maximum absorption of tile.

\begin{tabular}{cc}
\hline Quality Level & Maximum absorption $(\%)$ \\
\hline I & 12 \\
II & 15 \\
III & 20 \\
\hline
\end{tabular}

\subsection{Flexural Load Test}

Flexural load test is carried out under conditions of dry clay roof tile. Clay tile is placed on 2 support and gives the line burden on the middle of the span. Then observe the maximum load that causes the clay roof tiles to collapse.

According to SNI 03-6861.1-2002 [10], based on the strength of flexural load resistance, roof tile is divided into 5 levels: quality level I, II, III, IV and V, with standard values as in Table 2.

Table 2. Flexural Load Resistance.

\begin{tabular}{ccc}
\hline \multirow{2}{*}{ Qulity Level } & \multicolumn{2}{c}{ Flexural Load Resistance (Kgf) or Kg) } \\
\cline { 2 - 3 } & Average of at least 6 (six) tiles are tested & Minimum number for each tile tested \\
\hline I & 150 & 110 \\
II & 120 & 90 \\
III & 80 & 60 \\
IV & 50 & 35 \\
V & 30 & 25 \\
\hline
\end{tabular}

\section{Result and Discussion}

\subsection{Water Seepage Test}

The results of seepage test of clay tile with ash of rice husk $0 \%, 2.5 \%, 5 \%$ and $7,5 \%$, obtained no leakage or water droplets at the location in the water soak (Fig. 1).

\subsection{Absorption Test}

The results of testing the absorption of clay tile, there is a relationship of increasing the absorption of clay tile with the addition of RHA. The greater the addition of RHA on clay tile, the more water the clay tile is absorbed (Fig 2).

The addition of $7.5 \%$ husk ash to the clay tile resulted in an absorption of up to $18 \%$, this value almost close to the maximum allowable level for clay tile quality level III (absorption of $20 \%$ ). Absorption of clay tile with the addition of RHA $2.5 \%$ and $5 \%$ entered into the level of 
quality level II. And the tile without RHA (0\% RHA) enters the grade grade level I in absorption. And the tile without RHA (0\% RHA) enters the grade grade level I in absorption. RHA on clay tile has absorb water properties.

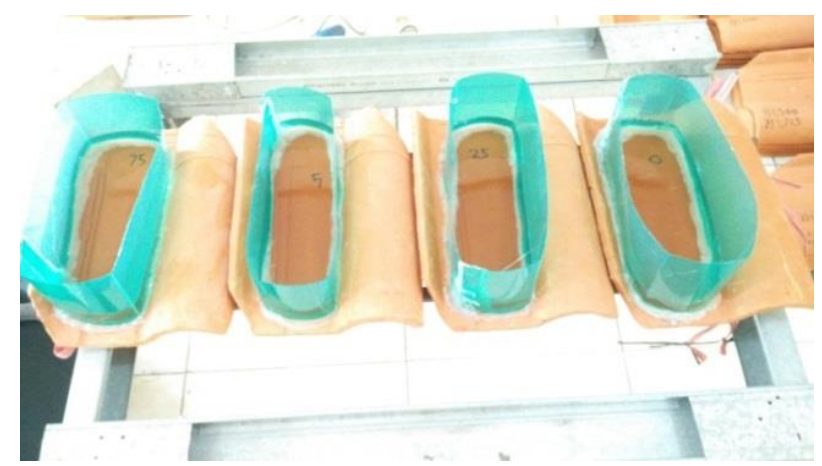

Fig. 1. Water Seepage Test of Clay Tile.

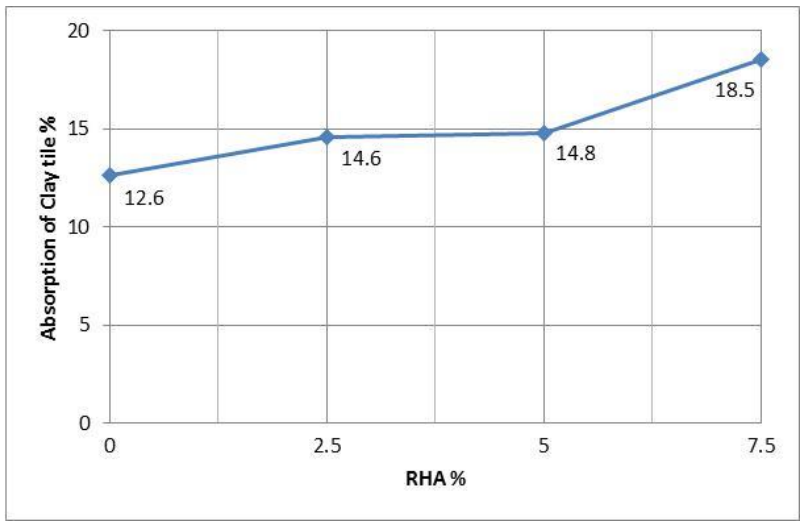

Fig. 2. Result of Tests for Absorption of Clay tile.

\subsection{Flexural Load Test}

The test results showed the addition of RHA can increase the flexural strength of the clay tile. Maximum flexural load was obtained by increasing the RHA by $7.5 \%$ which is average of $68.75 \mathrm{~kg}$, for the addition of 5\% RHA and $2.5 \%$ is $65 \mathrm{~kg}$ and $66.25 \mathrm{~kg}$. And clay tile without RHA produces a $60 \mathrm{~kg}$ bending load.

The difference in the flexural strength of the clay tile is due to the effect of the addition of RHA, which changes the soil strength properties. The silica content in RHA is able to fill the pore of clay tile, and its binding properties thus increasing the strength of the tile. In general, RHA has properties as a binder and fills the pores when mixed with other materials. 


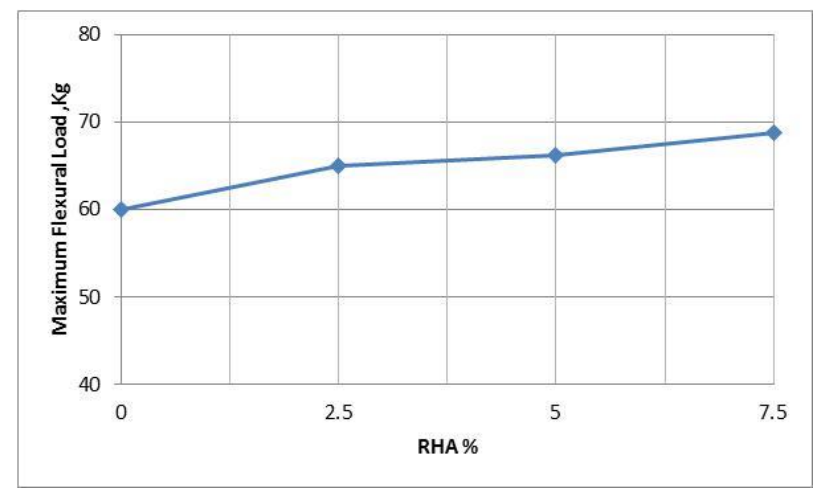

Fig. 3. Result of Tests for Flexural Load of Clay tile

\section{Conclusions}

Utilization of RHA as an added material clay tile can be used on a certain percentage. Clay tile with the addition of RHA $7.5 \%$ has a lighter weight than the addition of RHA 5\%, $2.5 \%$ and clay roof without RHA.

Clay tile with RHA addition of $7.5 \%$ has an average load resistance of $68.75 \mathrm{~kg}$, this result is highest compared to clay tile with addition of RHA 5\%, $2.5 \%$ and clay roof without RHA.

Clay tile without RHA addition has a quality level I in the absorption test, while clay tile with RHA $2.5 \%$; $5 \% ; 7.5 \%$ has a quality level II. In seepage test, all tiles have resistance to seepage.

\section{Acknowledgments}

This research was funded by BAPPEDA of Blora Regency under contract No. 070/2444/2017 as part of the Regional Superior Research program of Blora Regency 2017. In addition, the authors acknowledge the technical support provided by the Balong Blora clay tile industry partnership.

\section{References}

[1] H. Katsuki, S. Furuta, T. Watari, and S. Komarneni, "ZSM-5 zeolite/porous carbon composite: Conventional- and microwave-hydrothermal synthesis from carbonized rice husk," Microporous Mesoporous Mater., vol. 86, no. 1, pp. 145-151, 2005.

[2] H. Harsono, "Production of Amorphous Silica from Rice Husk Waste," J. Ilmu Dasar, vol. 3, no. 2, pp. 98-102, 2002.

[3] M. I. Kusuma, T. Tarkono, and M. Badaruddin, "The Influence of Addition of Rice Husk Ashes to Compressive Strength and Porosity of Prinsewu Clay tile," J. Fema, vol. 1, no. 4, pp. 1-6, 2013.

[4] N. V. Mohan, P. P. V. V Satyanarayana, and K. S. Rao, "Performance Of Rice Husk Ash Bricks," Int. J. Eng. Res. Appl., vol. 2, no. 5, pp. 1906-1910, 2012. 
[5] S. D. Kusumawati, "The Influence Of Substitution Of Clay Parts With Rice Ash And Rice Burning Viewed From Physical Characteristics And Coal Mechanics," 2012.

[6] A. Abdurrohmansyah, I. Adha, and H. Ali, "The Study of Compressive Strength Brick Using Additive Material (Ash Rice Husk, Ash Sugar Cane and Fly Ash) Based on Specification of Indonesian National Standard (SNI)," J. Rekayasa Sipil Dan Desain, vol. 3, no. 3, pp. 541-552, 2016.

[7] G. H. M. J. S. De Silva and M. L. C. Surangi, "Effect of waste rice husk ash on structural, thermal and run-off properties of clay roof tiles," Constr. Build. Mater., vol. 154, pp. 251-257, 2017.

[8] Ministry of Public Works of the Republic of Indonesia (Directorate of Inquiry on Building Problems), Indonesian Ceramic Tile Regulation NI-19. Bandung: Ministry of Public Works of the Republic of Indonesia, 1978.

[9] The National Standardization Agency of Indonesia, SK-SNI 03-2095 Ceramic Tile. Jakarta: The National Standardization Agency of Indonesia, 1998.

[10] The National Standardization Agency of Indonesia, SK-SNI 03-6861.1 Building Materials Non Metals. Jakarta: The National Standardization Agency of Indonesia, 2002. 